\title{
DECENTRALIZED AID AND DEMOCRACY
}

\section{Joaquín Morales Belpaire}

\section{ABSTRACT}

This paper uses a model of vote over public finances to show that when nongovernmental organisations deliver development aid, beneficiaries have incentives to reduce electoral support for state-led redistribution. As a result, NGOs can crowd out governmental spending, turning private aid into a negative externality for the poor who do not directly benefit from it. I model the choice of a representative NGO, which faces a trade-off between targeting beneficiaries with higher needs, and reducing costs. I characterize the conditions under which this targeting affects the size of the externality and describe how it affects the welfare of beneficiaries and non-beneficiaries.

Keywords: Private Development Assistance, Democracy, Governance, NGOs, Nonprofits, Foreign Aid, Taxation, Public Goods. 